\title{
Spina bifida and anencephaly: miscarriage as possible cause
}

\author{
Sir CYRIL CLARKE， D HOBSON， OLIVE M MCKENDRICK， S C ROGERS， P M SHEPPARD
}

British Medical fournal, 1975, 4, 743-746

\section{Summary}

In two retrospective Liverpool surveys the domestic, family, dietary, and medical environments of the mothers of children affected by anencephaly or spina bifida, or both (ASB) were examined. None seemed to be of more than minor importance and the findings of others were therefore examined to see if they suggested a major factor.

The most promising lead came from the hypothesis that ASB is usually due to an interaction between twin fetuses or between a fetus and residual trophoblastic material from the previous normal pregnancy, particularly when this is of the opposite sex to the propositus. The sex finding was not confirmed.

It was noted that hydatidiform moles, like children with ASB, were usually female and that moles and choriocarcinomas on the one hand and children with ASB on the other occurred in mothers of similar ages, but were to some extent reciprocal in geographical incidence. This suggested that trophoblastic disease might be a factor common to all three and if so then one would expect the frequency of miscarriages to be higher immediately before than immediately after the birth of an ASB child, since mole and choriocarcinoma seldom follow a normal pregnancy. An analysis of published data confirmed that this was almost certainly so. Hence residual pathological trophoblastic material from either a previous miscarriage or a co-twin may interact unfavourably with another fetus to produce ASB and this may be the primary cause of the condition. The hypothesis is consistent with the observed lack of concordance in twins, the high incidence in females, the maternal age effect, and the greater prevalence in social classes IV and $V$.

Nuffield Unit of Medical Genetics, University of Liverpool, Liverpool Sir CYRIL CLARKE, MD, PRCP, FRS, Nuffield research fellow

Department of Medical Microbiology, University of Liverpool, Liverpool

DEREK HOBSON, MD, MRCPATH, reader in medical microbiology

Liverpool Corporation

OLIVE M MCKENDRICK, MB, CHB, school medical officer

Rugby

S C ROGERS, MB, MRCGP, general practitioner

Department of Genetics, University of Liverpool, Liverpool

P M SHEPPARD, DPHIL, FRS, Hon FRCP, professor of genetics

\section{Introduction}

Many people have investigated environmental factors in the epidemiology of spina bifida or anencephaly or both (ASB). ${ }^{1-10}$ In a survey in Liverpool ${ }^{11}$ dealing with spina bifida only, we found several factors that were worth further investigation and which suggested others that might be relevant. We therefore undertook the survey reported here.

\section{Surveys}

In the second survey $\mathbf{5 4}$ mothers of children with spina bifida and also 35 with children with anencephaly were interviewed, together with a matched control for each mother to exclude the effects of social class, year of birth, and area of residence. Most of the results were analysed by a paired comparison using a $t$ test for quantitative and binomial distribution for qualitative data. When paired comparisons were not used either $\chi^{2}$ or $t$ was calculated.

Table I shows the factors for which there was no significant difference between the mothers of affected children and their controls in either survey. Table II shows factors in which controls did differ significantly from mothers of children with spina bifida in either series or those with children with anencephaly or anencephaly and spina bifida combined in this survey. A few points are worth mentioning.

As in previous surveys ${ }^{2}{ }^{12-14}$ we found a significantly shortened gestation period in anencephaly. There were also more females among children with anencephaly, but in our small series this was not significant. There were more cases of spina bifida and other types of congenital abnormalities among the sibs of ASB propositi. There was a significant age effect in the mother and also in the father, though the latter may have been due to the parents' ages being correlated. Renwick $^{8}$ suggested that potato blight might be important in the aetiology of ASB, and in both our surveys some aspect of potato consumption was significant in the direction suggested by Renwick's hypothesis, but the results were not consistent between the two investigations. Furthermore, the original hypothesis has been modified considerably. ${ }^{16}$

Several workers have emphasised the health of the mother during pregnancy. Thus McDonald ${ }^{3}$ suggested a relationship between con-

\begin{tabular}{|c|c|}
\hline $\begin{array}{l}\text { Family } \\
\text { Sex ratio in propositi } v \text { sibs } \\
\text { Position in sibship of propositi } v \text { sibs } \\
\text { Month of birth of propositus } v \text { sibs } \\
\text { Stillbirths and/or miscarriages }\end{array}$ & $\begin{array}{l}\text { Tomatoes per week } \dagger \\
\text { Tinned meat per week } \dagger \\
\text { Tinned fish per week } \\
\text { Tinned fruit per week } \dagger\end{array}$ \\
\hline $\begin{array}{l}\text { Stlllbirths and or miscarriages } \\
\text { in sibship } \\
\text { Maternal height } \dagger \\
\text { Maternal weight at onset of pregnancy } \dagger \\
\text { Maternal weight at interview } \\
\text { Anencephaly cases in immediate family } \\
\text { (when propositus has ASB) }\end{array}$ & $\begin{array}{l}\text { Medical (mother after conception) } \\
\text { Anaemia } \\
\text { Cystitis } \\
\text { Pyelitis } \\
\text { Toxaemia and high blood pressure } \\
\text { Iron } \\
\text { Vitamins }\end{array}$ \\
\hline $\begin{array}{l}\text { Domestic } \\
\text { Size of household }\end{array}$ & $\begin{array}{l}\text { Antibiotics } \dagger \\
\text { Antidepressants } \dagger\end{array}$ \\
\hline $\begin{array}{l}\text { Mother wearing gloves when peeling } \\
\text { potatoes }\end{array}$ & $\begin{array}{l}\text { Maternal antibodies }+ \text { to: } \\
\text { Influenza A (Hong Kong virus strain } \\
\text { A2/Eng/878/69) }\end{array}$ \\
\hline $\begin{array}{l}\text { Dietary (mother) } \\
\text { Cheese per week } \\
\text { Fresh fruit per week }\end{array}$ & $\begin{array}{l}\text { Rubella } \\
\text { Herpes simplex (type 1) } \\
\text { Cytomegalovirus }\end{array}$ \\
\hline
\end{tabular}


TABLE II-Factors significant in at least one of the Liverpool surveys. Plus or minus signs indicate that the mothers had, respectively, higher or lcwer scores than controls for the factcr being tested.

\begin{tabular}{|c|c|c|c|c|}
\hline \multirow{2}{*}{ Comparison } & \multicolumn{3}{|c|}{$P$ values in present survey } & \multirow{2}{*}{$\begin{array}{c}\begin{array}{c}P \text { values in } \\
\text { previous } \\
\text { survey }\end{array} \\
\begin{array}{c}\text { Spina } \\
\text { bifida }\end{array} \\
\end{array}$} \\
\hline & $\begin{array}{l}\text { Spina } \\
\text { bifida }\end{array}$ & $\begin{array}{l}\text { Anen- } \\
\text { cephaly }\end{array}$ & ASB & \\
\hline \multicolumn{5}{|c|}{ Family } \\
\hline \multirow{3}{*}{ 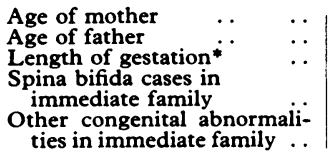 } & $\begin{array}{l}->0.1 \\
->0.05 \\
->0.2\end{array}$ & $\begin{array}{l}-<0.05 \\
->0.1 \\
-<0.001\end{array}$ & $\begin{array}{l}-<0.02 \\
-<0.01 \\
-<0.01\end{array}$ & $\begin{array}{l}->0.4 \\
->0.9\end{array}$ \\
\hline & $\begin{array}{r}0.031 \\
+\quad 0\end{array}$ & $1 \cdot 0$ & +0.016 & $+<0.05$ \\
\hline & $+\quad 0.625$ & $1 \cdot 0$ & $+\quad 0.508$ & $+>0.05$ \\
\hline \multicolumn{5}{|c|}{ Domestic } \\
\hline \multirow{3}{*}{$\begin{array}{l}\text { Help in preparation of food } \dagger \\
\text { Help with housework } \dagger \\
\text { Mother having job outside } \\
\text { household .. }\end{array}$} & $\begin{array}{l}+<0.01 \\
+<0.05\end{array}$ & $\begin{array}{l}+>0.1 \\
+>0.3\end{array}$ & $\begin{array}{l}+<0.001 \\
+>0.05\end{array}$ & $\begin{array}{l}+\geq 0.5 \\
+<0.01\end{array}$ \\
\hline & +0.029 & -0.38 & +0.188 & $->0.8$ \\
\hline & \multicolumn{4}{|c|}{ Dietary (mother) } \\
\hline $\begin{array}{lll}\text { Meat per week } & \ldots & \ldots \\
\text { Eggs per week } & \ldots & \\
\text { Total weight of potatoes eaten } \\
\text { Potatoes from the chip shop }\end{array}$ & $\begin{array}{l}->0.4 \\
->0.5 \\
+<0.02 \\
+<0.69\end{array}$ & $\begin{array}{r}+>0.2 \\
+>0.9 \\
+>0.5 \\
1.0\end{array}$ & $\begin{array}{l}+>0.7 \\
-\geq 0.6 \\
+<0.05 \\
+\quad 0.875\end{array}$ & $\begin{array}{l}-<0.05 \\
-<0.05 \\
->0.3 \\
+\quad 0.045\end{array}$ \\
\hline \multicolumn{5}{|c|}{ Medical (mother after conception) } \\
\hline \multirow{2}{*}{$\begin{array}{l}\text { Illnesses other than those in } \\
\text { in table I } \neq \text {. } \\
\text { Drugs other than those in } \\
\text { Table } 1\end{array}$} & $+0 \cdot 109$ & +0.180 & +0.019 & +0.033 \\
\hline & 1.0 & +0.581 & +0.701 & +0.018 \\
\hline
\end{tabular}

* Studied only in present survey.

+ Not studied by paired comparisons in the present survey.

‡Includes some just before conception.

genital malformations and febrile infections (or pulmonary tuberculosis) early in pregnancy or certain types of heavy work. Again, Coffey and Jessop ${ }^{4}$ presented evidence suggesting an increased incidence of anencephaly related to maternal influenza. In both our Liverpool series the mothers of affected children had had significantly more minor undefined illnesses (table II), but these had not been confined to the critical first weeks of pregnancy, and our retrospective viral antibody studies (table I) did not show a higher titre in the mothers of affected children. Neither did those of Elizan $e a l^{17}$ or Lapinleimu $e t$ al ${ }^{18}$ with respect to central nervous system defects in general.

Possibly relevant also to the health of the mother was our finding that more of the affected mothers had domestic help; perhaps they needed it because they were unwell. In the second survey, however, help was more related to having a job, and there were no more "other illnesses" among these particular mothers. These findings are a weak argument for maternal health being a factor, though they do support McDonald's view on work.

We concluded from these surveys that, though there are several factors that may be important in ASB, their effects are minor, and we therefore examined published studies to see whether there was any other non-genetic aspect which might be of major importance.

\section{HYPOTHESES}

Rogers ${ }^{19}$ suggested that one explanation for the rarity of twins concordant for ASB (see Imaizumi ${ }^{20}$ for some detailed Japanese data) might be that affected fetuses fused to produce conjoined twins, which would therefore not be scored as ASB. Knox ${ }^{1122}$ put forward the fetus-fetus hypothesis that the deficiency of discordant unlike sex twins might be caused by dizygous twins interacting, particularly when they were of different sexes, such that one twin disappeared while the damaged survivor was anencephalic, affected twin pairs representing the survivors of triplets. The hypothesis fitted the known facts only roughly, and Knox postulated that residual trophoblast material from a previous normal pregnancy in which the baby was of different sex from the infant with ASB might also cause an interaction. Residual abortus trophoblast might also behave in the same way.

Rogers ${ }^{23}$ has amplified the hypothesis. If nidation of a subsequent pregnancy occurred in proximity to residual trophoblastic material (a rest) this material might be activated and a mosaic placenta formed, but the cellular elements derived from this previous trophoblast might be at an inappropriate stage of maturity. This might lead to a change in the timing of embryological events, resulting, on the one hand, in ASB or facial clefts or, on the other, in abnormal fusions such as syndactyly or gut atresias. Furthermore, the patch of skin with coarse hair often found over the defect in spina bifida might be a relic of the rest. Rogers's hypothesis would explain the rarity of concordant affected twins since for them to occur both would have to be in close proximity to the rest.

Knox's2 ${ }^{22}$ main evidence for the interaction between sequential pregnancies was that the sex ratio among children immediately before affected females was different from that before affected males (although the calculation of the $\chi^{2}$ shows that this was not significant) and that the sex ratio before affected females was different from that of all their other sibs. His information was obtained from Record and McKeown. ${ }^{12}$ The only sufficiently detailed data on families with affected children are the extensive studies of Carter et al ${ }^{13}$ and Carter and Evans ${ }^{14}$ and the smaller one of Williamson. ${ }^{7}$ Carter and Evans did not record miscarriages, ${ }^{*}$ so that it was impossible to know whether the preceding child was the immediately preceding pregnancy or not. Williamson's study was too small for our purpose. Hence only the data of Carter et al $^{13}$ could be used to test Knox's analysis. In these there was absolutely no suggestion of a disturbed sex ratio among sibs immediately before an affected child for either sex of propositi (table III). Thus these data did not support that part of Knox's hypothesis that deals with sex interaction.

TABLE III-Sex ratio in sibships of infants with anencephaly or spina bifida ${ }^{13}$

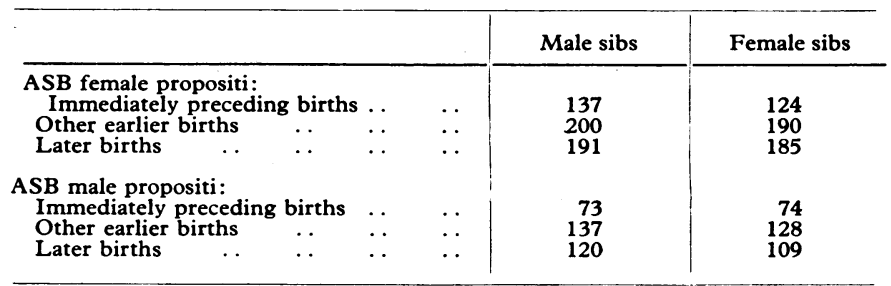

TABLE IV-ASB in relation to miscarriages and stillbirths: combined data from other studies ${ }^{71} 1314$ and present survey with data on children with hydrocephalus for comparison? 1213

\begin{tabular}{|c|c|c|c|c|}
\hline & \multicolumn{2}{|c|}{ No of Miscarriages } & \multicolumn{2}{|c|}{ No of stillbirths } \\
\hline & Before & After & Before & After \\
\hline \multicolumn{5}{|c|}{$A S B$ Propositi } \\
\hline $\begin{array}{l}\text { First pregnancy, child affected. } \\
\text { "Middle" child affected } \\
\text { Last pregnancy, child affected.. }\end{array}$ & $\begin{array}{l}68 \\
49\end{array}$ & $\begin{array}{l}25 \\
34\end{array}$ & $\begin{array}{l}13 \\
18\end{array}$ & $\begin{array}{l}5 \\
6\end{array}$ \\
\hline \multicolumn{5}{|c|}{ Children with hydrocephalus } \\
\hline $\begin{array}{l}\text { First pregnancy, child affected. } \\
\text { "Middle" child affected } \\
\text { Last pregnancy, child affected.. }\end{array}$ & $\begin{array}{l}3 \\
2\end{array}$ & $\begin{array}{l}1 \\
4\end{array}$ & $\begin{array}{l}1 \\
2\end{array}$ & $\begin{array}{l}1 \\
0\end{array}$ \\
\hline
\end{tabular}

\section{MISCARRIAGES}

We thought that we might be able to find additional data for or against the hypothesis that trophoblastic tissues are important in the causation of ASB. Half of all miscarriages are the result of a blighted or diseased ovum which in extreme cases progresses to a hydatidiform mole. ${ }^{15}$ This in its turn may develop into choriocarcinoma. Choriocarcinoma in over three-quarters of the cases follows a mole or a miscarriage rather than a normal delivery, ${ }^{24}$ which suggests that the retention of pathological trophoblastic material is much more likely to occur after a miscarriage than after a normal delivery (though the interpretation could be that it is more likely to become cancerous than more likely to occur). If a rest is more common after a miscarriage, and if ASB is due to an interaction between it and the next pregnancy, as suggested by Knox and Rogers, then miscarriages (and possibly stillbirths) should be commoner directly before an affected individual than directly after. This may be examined from the published sibships.

The family data must be analysed with caution, however, since first or, particularly, last children tend to be the ones affected with ASB. ${ }^{8}$ If miscarriages were randomly distributed this would automatically lead to a higher proportion of miscarriages immediately before an affected child. We therefore examined the data of Carter et $a l,{ }^{13}$ Carter and Evans, ${ }^{14}$ and Williamson ${ }^{7}$ and our own data from the two surveys, using only those sibships in which at least one pregnancy had occurred both before and after the affected child. Table IV

*The term miscarriage is used throughout the paper to prevent any confusion with therapeutic abortion. 
gives the results for miscarriages and stillbirths in the pregnancies immediately before and after. There were always more miscarriages and stillbirths before the affected children than immediately after.

Only the data of Carter et $a l^{13}$ were sufficiently extensive to show a significant difference on their own but the data of all surveys for miscarriages and stillbirths combined showed an immensely significant difference $\left(\chi^{2}=13.9 ; \mathrm{DF}=1 ; \mathrm{P}<0.001\right)$. We could not determine whether the discrepancy resulted from a high miscarriage rate before or a lower one afterwards since there was no published control series from which we could calculate valid expected numbers. It was probably due, however, to an increase before the affected child (see Discussion).

If the immediately preceding miscarriage is important in the aetiology of ASB then one would expect to find a higher proportion of miscarriages before the last child, when it is affected, than after the first child, when it is affected. Our analysis of the data of Carter et al ${ }^{13}$ showed 22 miscarriages immediately after the 325 first children when they were affected and 41 immediately before the 406 last affected children (counting a single pregnancy in a family as producing both a first and a last affected propositus). These findings were consistent with our hypothesis, since there were more miscarriages before an affected child than after, though the difference was not significant $(\mathbf{P}>0 \cdot 2)$.

\section{POSSIBLE EXPLANATIONS}

There seem to be three possible explanations of these findings.

Firstly, miscarriages possibly tend to occur early rather than late in families, but the data gave no evidence for such a view, and in one series (anencephaly in Appendix 1 of Carter et al $^{13}$ ) miscarriages came on average significantly later. Thus a tendency for miscarriages to occur early probably does not account for our results.

Secondly, women who have had an affected child might think that a previous miscarriage had had something to do with the subsequent trouble and might therefore be more likely to report it. More probably, however, they would report all miscarriages, but even if they did not this type of biased reporting would be equally likely to occur with other congenital malformations, and there was no suggestion in studies of hydrocephalus without spina bifida ${ }^{72} 13$ that reported miscarriages tended immediately to precede the propositus (table IV). The difference between hydrocephalus and ASB was not, however, significant with such small numbers in the hydrocephalus series $(P>0 \cdot 1)$

Thirdly, the data might be explained by an environmental factor predisposing to both ASB and miscarriages, but this would be equally likely to affect consecutive pregnancies, whether the miscarriage was before or after the affected infant assuming equal mean intervals between conceptions (here about 20 months with miscarriages before and 24 after the propositus).

Thus these three explanations may be fairly certainly rejected, and the data are therefore consistent with trophoblastic rests being related to subsequent cases of ASB.

\section{Discussion}

There is much support in published findings for the observation that miscarriages, stillbirths, and neonatal deaths are particularly common in the pregnancy immediately before an ASB child. Smithells and Chinn ${ }^{25}$ found this in spina bifida and Smithells et $a l^{26}$ in anencephaly. Much earlier Murphy ${ }^{27}$ noted a similar concentration of miscarriages immediately before congenital malformations generally but did not analyse ASB separately. He also suggested that miscarriages were common immediately after the malformed child, but much less so. Richards $e t a^{28}$ also noted a considerably higher miscarriage rate $(17 \cdot 1 \%)$ before the affected child than afterwards $(11.6 \%)$ when the propositus had spina bifida, but the figures did not relate specifically to the immediately preceding or succeeding pregnancies.

The data of Record and McKeown ${ }^{12}$ also show that miscarriages and still-births are more common immediately before the birth of a child with any malformation of the central nervous system, and most of their cases were of ASB. They also found a slightly raised incidence of miscarriages two pregnancies before the propositus. In none of these surveys is it possible from the published data to exclude the first and last affected child, and none of the authors puts forward an explanation of the facts.
These data all support the view that the results (table IV) are due to a higher miscarriage rate before an affected child rather than a lower one after. Both views imply an interaction between consecutive pregnancies, but it is difficult to find any physical explanation for an abnormally low miscarriage rate immediately after an affected child.

Social class-The rest hypothesis might be consistent with an effect of social class. There is some evidence that miscarriages are slightly more common in later pregnancies, ${ }^{29} 30$ and therefore in the past, when women of social classes IV and V tended to have more children than others, they would also tend to have more miscarriages. Furthermore, it seems probable that this group would have been less likely to seek advice and receive obstetric attention after any miscarriage, which might have led to a higher incidence of rests. In addition, since the mean interval between a miscarriage and the next ovulation is only 50 days $^{31}$ the presence of a rest at the beginning of the next pregnancy after a miscarriage is far more likely if contraceptive precautions are not taken, and therefore religious and cultural influences might be important. The effect of social class has been noticed often (see for example Edwards ${ }^{2}$ ) but is now apparently diminishing in some places. ${ }^{32}$

Counter-evidence-Against the hypothesis that residual trophoblastic material is important, and on the assumption that this disappears fairly quickly, is our finding that there was no significant difference in mean time interval between an ASB or a normal child and an immediately preceding miscarriage (in the data of Carter $\mathrm{et}_{\mathrm{al}} \mathrm{l}^{13}$ ). The mean period in both is short, however, so that unless rests normally disappear very rapidly one might not be able to detect a difference except in very extensive data. In the case of moles rests may sometimes persist for many years. ${ }^{24}$ The findings of Roberts and Lloyd ${ }^{29}$ also do not support the rest hypothesis, since they found an inverse relationship between the frequency of neural tube defects and miscarriage rate in two areas of South Wales. Furthermore, the rest hypothesis is not very convincing in relation to the high prevalence of anencephaly in first pregnancies, and the many cases of ASB in which no previous miscarriage is recorded, but the rate of pregnancy wastage in the first month is high, particularly in very young and old mothers, ${ }^{15}{ }^{33}$ and many of these are likely to go unnoticed by the mother. ${ }^{15}$

Relation between $A S B$ and mole and choriocarcinoma-There is a suggestion of a negative geographic correlation between the frequency of $\mathrm{ASB}$ and that of mole and choriocarcinoma. For example, ASB is rare in Japan ${ }^{8}$ and mole and choriocarcinoma common $^{24}$; the reverse is the case in Europe and North America. It may be pertinent that all three conditions are most common in mothers under 20 and over $40 . .^{84}{ }^{34}$ There is no evidence, however, on whether they have a common cause, although one is an interaction between the trophoblast and the mother, ${ }^{35}$ and the other, on Knox's and our hypothesis, an interaction between the trophoblast and the fetus. Since there is a complicated relationship between the $\mathrm{ABO}$ blood group of the mother and the choriocarcinoma or mole, ${ }^{35}$ which is reflected in the groups of father and mother, it would be well worth investigating this in cases of ASB.

Our analysis seems to support the interaction hypothesis. This hypothesis could explain the lack of concordance in twins and if the sex of the rest is important the high preponderance of affected females. Moles ${ }^{24}$ are predominantly female, and if the interaction is particularly severe if the rest and the next fetus are of unlike sex, as Knox ${ }^{2122}$ suggested in his fetus-fetus hypothesis, it might result in males being more severely affected and miscarried. There is in fact evidence for preferential miscarriage of males in anencephaly..$^{36}$

\section{FURTHER STUDIES}

We think that the case is sufficiently strong to pursue the matter further. This could be done by looking for evidence of genetic mosaicism in the placentae of ASB children (for instance 
by placental enzyme studies) as well as following up subsequent pregnancies in therapeutic abortions to see if there is a higher or lower incidence of ASB after these than after miscarriages. If the ASB is due to a diseased rest then we would expect it to be rare after therapeutic abortions. It would also be worth undertaking a prospective survey in antenatal clinics in an area with a high incidence of ASB by questioning mothers about possible previous miscarriages when they first presented, and when one is reported picking a matched control with no such history. A comparison of the frequency of ASB in the two groups might well support or refute the role of miscarriage after a reasonable length of time. Since we suggest that the primary cause of ASB is the presence of a rest, the most direct test is to find a method of detecting its presence. This might be possible by determining the chorionic gonadotrophin levels in mothers after normal pregnancies and after miscarriages.

Fairly extensive cytogenetic studies have been done in ASB and in general the chromosomal sex parallels that of the phenotype. Arias-Bernal and Jones, ${ }^{37}$ however, reported an anencephalic male with an XX sex chromosome complement in cells derived from abdominal skin, and $\mathrm{Wiesli}^{38}$ found a male anencephalic who was sex-chromatin positive as judged by testing amnion cells from the placenta. So far as we know no one has sexed the hairy patch of skin sometimes present over the defect in spina bifida and we plan to do this.

The rest hypothesis does not exclude environmental factors being of some importance because they might increase the likelihood of a rest occurring. Furthermore, in the presence of a rest there is no suggestion that it, even if in contact with the next conceptus, would necessarily interact unfavourably with it. An interaction might be more likely to occur perhaps after intercurrent infections with viruses such as measles, which often produce chromosome breaks and fusion of cells. ${ }^{3940}$

We think that the clue to the cause of ASB lies in "the baby before," a state of affairs not unknown in another branch of paediatrics. $^{41}$

We thank the mothers who took part in the Liverpool surveys and the health visitors in the Merseyside Region for their enthusiastic help and co-operation. We are indebted to Dr G Bruce White of the Public Health Laboratory, Liverpool, for providing some of the viral antigens. We are particularly grateful to the Nuffield Foundation for its continued support.

Requests for reprints should be addressed to Sir Cyril Clarke. The full data for the present Liverpool survey is also available.

\section{References}

1 Penrose, L S, Fournal of Mental Deficiency Research, 1957, 1, 4.

${ }^{2}$ Edwards, J H, British fournal of Preventive and Social Medicine, 1958, 12, 115.

3 McDonald, A D, New England fournal of Medicine, 1958, 258, 767.

4 Coffey, V P, and Jessop, W J E, Lancet, 1959, 2, 935.

5 Coffey, V P, and Jessop, W J E, Lancet, 1963, 1, 748.

6 Lorber, J, Pediatrics, 1965, 35, 589.

7 Williamson, E M, Fournal of Medical Genetics, 1965, 2, 161.

${ }^{8}$ Renwick, J H, British fournal of Preventive and Social Medicine, 1972, 26, 67.

${ }^{9}$ Knox, E G, British fournal of Preventive and Social Medicine, 1972, 26, 219.

10 Spira, N, et al, La Revue de Médecine, 1972, 13, 2683.

${ }^{11}$ Clarke, C A, McKendrick, O M, and Sheppard, P M, British Medical fournal, 1973, 3, 251.

12 Record, R G, and McKeown, T, Britısh fournal of Social Medicine, 1950, 4, 26:

13 Carter, C O, David, P A, and Laurence, K M, fournal of Medical Genetics, 1968, 5, 81 .

${ }^{14}$ Carter, C O, and Evans, K M, Fournal of Medical Genetics, 1973, 10, 209.

${ }^{5}$ Hertig, A T, Human Trophoblast, p 363. Springfield, Illinois, Charles C Thomas, 1968.

${ }^{16}$ Renwick, J H, Possamai, A, and Munday, M R, Proceedings of the Royal Society of Medicine, 1974, 67, 360.

17 Elizan, T S, et al, Archives of Neurology, 1969, 20, 115.

18 Lapinleimu, K, et al, Lancet, 1974, 1, 1127

19 Rogers, S C, Developmental Medicine and Child Neurology, 1969, 11, 617.

20 Imaizu mi, Y, Japanese fournal of Human Genetics, 1974, 19, 115.

${ }^{21}$ Knox, E G, Developmental Medicine and Child Neurology, 1970, 12, 167.

${ }^{22} \mathrm{Knox}, \mathrm{E}$ G, British fournal of Preventive and Social Medicine, 1974, 28, 73

23 Rogers, S C, in press.

${ }^{24}$ Bagshawe, K D, Choriocarcinoma, p 360. London, Edward Arnold, 1969.

${ }^{25}$ Smithells, R W, and Chinn, E R, Developmental Medicine and Child Neurology, 1965, 7, 258.

${ }^{26}$ Smithells, R W, Chinn, E R, and Franklin, D, Developmental Medicire and Child Neurology, 1964, 6, 231.

27 Murphy, D P, Surgery, Gynecology and Obstetrics, 1936, 62, 585.

${ }^{28}$ Richards, I D, McIntosh, H T, and Sweenie, S, Developmental Medicine and Child Neurology, 1972, 14, 626.

${ }^{29}$ Roberts, C J, and Lloyd, S, British Medical fournal, 1973, 4, 20.

${ }^{30}$ Knill-Jones, R P, Newman, B J, and Spence, A A, Lancot, 1975, 2, 807.

${ }^{31}$ Ratten, G J, Australian and New Zealand fournal of Obstetrics and Gynaecology, 1972, 12, 217.

32 Coffey, V P, Fournal of the Irish Medical Association, 1974, 67, 553.

${ }^{33}$ Novak, E R, and Woodruff, J D, Gynaecologic and Obstetric Pathology, 7 th edn, Philadelphia, Saunders, 1974.

34 British Medical fournal, 1975, 3, 606

${ }^{35}$ Bagshawe, K D, et al, Lancet, 1971, 1, 553.

36 Polani, P E, Lancet, 1959, 2, 240.

37 Arias-Bernal, L, and Jones, H W, American fournal of Obstetrics and Gynecology, 1967, 99, 877.

${ }^{38}$ Wiesli, B, Acta Anatomica, 1962, 51, 377.

39 Cascardo, M R, and Karzon, D T, Virology, 1965, 26, 311.

40 Stich, H F, and Yohn, D S, Progress in Medical Virology, 1970, 12, 78

41 Clarke, C A, British Medical fournal, 1967, 4, 7.
A middle-aged woman had a total hysterectomy and bilateral oophorectomy several years ago for a small carcinoma of the body of the uterus which was confined to the endometrium. What, if any, is the correct hormonal treatment of the symptoms from which she still suffers: vaginitis, sweats, loss of libido, and postmenopausal-type adiposity?

Experimentally many cancers of the body of the uterus may be shown to be oestrogen dependent, and since there is interdependence of all sex steroids in their metabolism, any such steroids could be a prop to surviving cancer cells. These are known to remain dormant in some instances for decades. It would be a tragedy to light up the cancer again. So the short answer is that no steroids should be given to this patient. The price of her "cure" is the symptoms she now suffers.

Is there any evidence that powder used on contraceptive diaphragms or condoms can pass through the Fallopian tubes into the peritoneal cavity?

There is no definite evidence that this occurs, but there is no inherent reason why it should not. The usual flow of fluid in the female genital tract is from the fimbriae of the Fallopian tube towards the exterior, but at least during orgasm probably the flow is reversed. Powder particles (usually of talc, which is magnesium silicate) are often smaller than spermatoza. In some ovarian cancers crystals morphologically identical with magnesium silicate have been discovered. A theory implicates this substance in the aetiology of ovarian cancer and correlates it with the increasing use of powdered toilet preparations puffed on and otherwise applied to the external genitalia.
A man awaiting reassessment for prostatectomy is inconvenienced by slight incontinence. Is there any treatment for this problem?

Prostatic obstruction leads initially to detrusor hypertrophy and increased voiding pressures. Later, detrusor decompensation may occur and residual urine develops. This stage is usually associated with reduced urine flow rates and a flow pattern that is characteristically prolonged and intermittent. Some terminal dribbling is not uncommon. Whether or not the patient complains of this depends as much on his personality - or that of his wife who washes his clothesas on the amount of urine loss. Provided chronic retention has been excluded and the leakage of urine occurs only after voiding, then instructions to adopt a more leisurely approach to micturation, appropriate to the patient's age and flow rate, may be all that is needed. Alternatively, the simple expedient of a small piece of absorbent material (for instance, cut from a disposable nappy roll) or the use of a light-weight catchment appliance designed for small urine losses, should provide a satisfactory solution while awaiting prostatectomy. It should be remembered, however, that some patients after prostatectomy notice slight dribbling after voiding, which is due to incompetence of the bladder neck and some impairment of the urethral closure mechanisms, but this usually improves with time. Leakage of urine associated with urgency or occurring at times other than after voiding should alert the doctor to the need for further investigations, including urodynamic studies, before the prostate is either implicated or removed. 